\title{
India and the United States agree on vaccine programme
}

New Delhi

INDIA and the United States have decided to go ahead with the implementation of the Indo-US Vaccine Acting Programme (VAP) despite the controversy stirred up by the signing of this agreement in July 1987 (see Nature 328, 287; 1987).

This decision was announced at the end of the first meeting of the Joint Working Group (JWG) co-chaired by Dr A.S. Paintal, director-general of the Indian Council of Medical Research, and Dr Nyle Brady of the US Agency for International Development. The group, consisting of eight scientists from each of the two countries, has been set up to direct the five-year programme against the most important diseases in India: viral hepatitis, diarrhoea, pertussis, animal rabies, respiratory infections and polio.

Originally scheduled for launch in September last year, VAP became bogged down in a controversy because of fears among the Indian science community that it would make India a testing ground for genetically engineered vaccines developed in the United States and that the US government would be the beneficiary of militarily sensitive epidemiological data. Paintal himself was of the view that no vaccines should be tested in India unless they had already been approved for use in the United States, and Dr G.S. Bhargava, a noted molecular biologist, was critical of trying imported recombinant vaccines on people before India has its own production and quality control facilities.

The Indian government's answer was to create an apex committee with Paintal as chairman and Bhargava as one of the members. All VAP activities must be cleared by this committee before submission to JWG for implementation. The government also assured the critics that no American will be directly involved in collection of epidemiological data. Ethical guidelines for conduct of human trials and a framework for sharing the intellectual property arising out of VAP have been spelled out in mutually agreed documents that are currently being scrutinized by the Indian law ministry.

The US team was particularly annoyed at the fuelling of the VAP controversy in India by the row over trials of the Wistar Institute's vaccinia-rabies recombinant vaccine on cows in Argentina. The reasons for the Argentine controversy "were purely political and not scientific", said Professor Frederick Robbins, a JWG member and Nobel laureate from Case Western Reserve University. He hoped India would not abandon trial of this vaccine on stray dogs because of what happened in Argentina. Dismissing specu- lation that the US interest in VAP was driven by commercial or other motives, he said: "We are in it because it made good foreign policy. But I care a damn whether Indians want to test our vaccines or not".

The JWG has scheduled its next meeting for October in Washington, by which time concrete research proposals will have been received from identified investigators in India and the United States. According to Paintal, the apex committee will examine each proposal from ethical, safety and environmental aspects.

With the hurdles removed, VAP is set for a start, but doubts remain whether the availability of new vaccines will in itself contribute to the improvement of Indian health. Tuberculosis has been on the rise although BCG vaccination has been part of childhood immunization for 30 years, and tetanus is the principal killer of children in India despite the availability of an effective vaccine. According to Dr Jacob John, a member of JWG and a virologist at the Christian Medical College in Vellore, vaccinated individuals constitute 30 per cent of total paralytic polio cases in the country although the same vaccine has virtually eradicated polio from Europe and the United States. It remains to be seen whether high-technology vaccines would be more effective than protected water supply and improved sanitation in preventing deaths from typhoid and diarrhoea.

\section{Change of heart in West German bacterial release debate}

\section{Munich}

WEST Germany has moved a step closer to approving the limited release of genetically engineered microorganisms. Experts from research and industry spoke out against a proposed five-year moratorium on the release of genetically engineered microorganisms at a parliamentary hearing in Bonn on 2 March. A single biologist backed a moratorium but approved of small releases as long as they could be proved "reversible". The hearing was marked by a lack of polemic, in contrast to the sharp public debate spurred by a release experiment last year in Bayreuth (see Nature 328, 568; 1987).

The five-year moratorium was proposed last year in the report of a parliamentary commission convened to assess the risks of genetic engineering. The commission would have allowed plant and animal releases if approved by the Central Committee for Biological Safety (ZKBS), a division of the Federal Health Office. Initially, all the large political parties supported a moratorium.

The Christian Democratic Union (CDU), which shares power with two smaller parties in the ruling Bundestag (parliament) coalition, is now moving towards permitting "smaller experiments" for the purpose of safety assessment, according to CDU Bundestag member Heinrich Seesing. The CDU fears new industries might be damaged by a moratorium but Seesing denied that economics were the party's only reason for its change of heart.

The issue will be dealt with in a sweeping "gene law" due to be completed by the Health Ministry later this year. Under current law, release of genetically manipulated plants, animals or bacteria is allowed only with the permission of the
ZKBS. Technical regulations for release of any genetically engineered organism are expected to be available before the new law is complete, possibly by the end of April. They will specify the criteria by which the ZKBS should judge release applications. No application has so far been approved but at least two new applications are expected this year.

The European Community (EC) is also expected to issue guidelines later this year. The European Parliament is considering a number of proposals, some of which would ban all types of release.

The lone supporter of a moratorium at the hearing was biologist Berndt Heydemann of the University of Kiel. Heydemann said that a five-year ban would not be long enough to determine the impact of the altered organisms on the surrounding ecosystem. Ten to fifteen years of observations would be needed before conclusions could be drawn. Heydemann also pointed out the shortage of funds for risk assessment research in ecology, a concern shared by WolfMichael Catenhusen (SPD), chairman of the Bundestag Research and Technology Committee. Catenhusen continues to favour a moratorium.

But the other experts, including ZKBS chairman Werner Goebel, called for a case-by-case review of all release experiments. Koln biologist Jozef St Schell declared that a moratorium would create the false impression that genetically manipulated organisms present an "uncontrollable menace" and that West German institutions are unprepared to oversee and regulate release experiments.

West Germany's Green Party continues to call for a ban on all genetic engineering and a moratorium on release. But the tide seems to have turned. Steven Dickman 